\title{
Polymorphism of the Beta Gene in Homozygous Sickle Cell Patients in Senegal and Its Influence on the Main Complications of the Disease
}

\author{
Dominique Doupa ${ }^{1}$, Moustapha Djité ${ }^{3}$, Pape Matar Kandji ${ }^{3}$, Demba Makalou ${ }^{1}$, Sira Thiam ${ }^{1}$, \\ Ousseynou Boye', Fatimetou Veten ${ }^{6}$, Aminata Lam $^{2}$, Marie Pierre Diouf ${ }^{2}$, Arame Ndiaye ${ }^{4}$, \\ Blaise Felix Faye ${ }^{5}$, Souleymane Thiam ${ }^{4}$, Abdourahmane Samba ${ }^{4}$, Fatou Diallo ${ }^{4}$, \\ Sidy Mohamed Seck ${ }^{1}$, Ahmed Ould Houmeida ${ }^{6}$, Papa Madieye Gueye ${ }^{3}$, Ibrahima Diagne ${ }^{1}$, \\ Saliou Diop 5 \\ ${ }^{1}$ Department of Medical Biochemistry, Saint-Louis University, Saint-Louis, Senegal \\ ${ }^{2}$ Department of Parasitology, Dakar University, Dakar, Senegal \\ ${ }^{3}$ Department of Pharmaceutical Biochemistry, Dakar University, Dakar, Senegal \\ ${ }^{4}$ Department of Medical Biochemistry, Dakar University, Dakar, Senegal \\ ${ }^{5}$ Department of Haematology, Dakar University, Dakar, Senegal \\ ${ }^{6}$ Department of Molecular Biology, Nouakchott University, Nouakchott, Mauritania
}

Email address:

d_doupa@hotmail.com (D. Doupa),dominique.doupa@ugb.edu.sn (D. Doupa)

To cite this article:

Dominique Doupa, Moustapha Djité, Pape Matar Kandji, Demba Makalou, Sira Thiam, Ousseynou Boye, Fatimetou Veten, Aminata Lam, Marie Pierre Diouf, Arame Ndiaye, Blaise Felix Faye, Souleymane Thiam, Abdourahmane Samba, Fatou Diallo, Sidy Mohamed Seck, Ahmed Ould Houmeida, Papa Madieye Gueye, Ibrahima Diagne, Saliou Diop. Polymorphism of the Beta Gene in Homozygous Sickle Cell Patients in Senegal and Its Influence on the Main Complications of the Disease. Advances in Biochemistry. Vol. 6, No. 3, 2018 , pp. 19-25. doi: 10.11648/j.ab.20180603.11

Received: August 3, 2018; Accepted: September 1, 2018; Published: September 21, 2018

\begin{abstract}
Sickle cell disease has a great variability of clinical and biological expression that depends on modulatory and environmental genetic factors. This variability in clinical and biological expression encourages us to look for predictors of severity. Hemoglobin F and its genetic determinants are influencing prognostic factors. The objectives of this study were to: determine the prevalence of the Senegal haplotype in homozygous sickle cell patients, study the relationship between this haplotype and the hemoglobin F level and evaluate its influence on the complications of the disease. This is a cross-sectional prospective study that included 100 homozygous sickle cell patients aged over 15 years. A questionnaire was used to collect epidemiological, clinical and biological variables. The hemoglobin F level was measured by capillary method and the analysis of point mutations by restriction fragment length polymorphism (RFLP). These data were collected and analyzed with the software Epi-info 7.2. A value $\mathrm{p} \leq 0.05$ was considered significant. The Senegal haplotype was found in $90 \%$ of patients, of whom $58 \%$ were homozygous for this mutation and 32\% were heterozygous. The hemoglobin F level averaged 9.5\% $\pm 8.3 \%$ and correlated statistically significantly with the allelic frequency. However, only bilary lithiasis correlated with the Senegal haplotype $(\mathrm{p}<0.005)$. This study confirms the homogeneity of the Senegal haplotype in the Senegalese sickle cell population and its influence on the synthesis of hemoglobin F. On the other hand, it revealed the existence of a relationship between the Senegal haplotype and bilary lithiasis suggesting the role of this haplotype in the protection against polymerization and hemolysis globally.
\end{abstract}

Keywords: Sickle Cell Disease, Haplotypes, $\beta$ Gene, Senegal 


\section{Introduction}

Although the mutation is unique (GAG GTG) at the 6 codon of the $\beta$-globin gene), the clinical and biological expression of sickle cell disease varies considerably depending on the geographical region. These differences are largely related to environmental factors (climate, social level, pathologies, etc.) but also to other genetic factors that have not been fully elucidated. Thus, based on analyzes of point mutations resulting in the restriction fragment length polymorphism (RFLP) whose association determines the haplotype, five main foci of sickle cell disease have been described that confirm the multicentric origin of the mutation: the Arabo-Indian haplotype, Benin, Cameroon, Bantu or Central African and Senegal which respectively correspond to specific geographical areas [1]. A relationship between haplotype and hemoglobin $\mathrm{F}(\mathrm{HbF})$ has been demonstrated. In fact, in carriers of the Senegal and Indian haplotype, a higher hemoglobin F level was observed (Lai et al [2] Neonato et al [3]). On the other hand, a relationship between these haplotypes and a lower frequency of the main complications remain controversial Labie et al, [4] Figueiredo et al [5].

Few data in the literature address genetic modulatory factors of sickle cell disease. Therefore, our objectives are: to study the prevalence of Senegal haplotype in homozygous sickle cell patients, to establish the relationship of this haplotype on the rate of production of hemoglobin $\mathrm{F}$ and its influence on the complications of disease.

\section{Patients and methods}

A prospective study was conducted from September 2015 to February 2016 looking at 100 homozygous sickle cell patients over the age of 15 years in the stationary phase regularly followed in this center. The stationary phase is defined by the absence of complication and acute manifestation of sickle cell disease within 15 days prior to recruitment. An EDTA sampling tube was collected from all patients for a blood count and molecular study by PCR / RFLP (Polymerase Chain Reaction / Restriction Fragment Lenght Polymorphism) was done for the detection of point mutations resulting in the polymorphism of a restriction site whose association determines the haplotype. This was a simple random sampling on a population of 1400 sickle cell regularly monitored in this center.

\subsection{Inclusion Criteria}

The inclusion criteria were as follows:

a 15 years old and over

b Agreement to participate in the study by written informed consent and signed by the patient

c No signs or symptoms of acute complications of sickle cell disease within 15 days prior to recruitment

d Electrophoretic profile confirmed by electrophoresis of hemoglobin

\subsection{Exclusion Criteria}

Patients with other chronic diseases were excluded from this study, including those whose clinical records were unusable because they lacked essential epidemiological data.

\subsection{Ethical Considerations}

Free and informed consent (verbal or written) of all persons included in this study was obtained beforehand.

\subsection{Complete Blood Count (CBC) (by Coulter ABX Pentra Nexus DX Machelen, Belgium)}

A venous blood sample was drawn from participants on an empty stomach, at rest and by venipuncture at the bend of the elbow. The blood was collected in tubes containing EDTA as anticoagulant.

a The blood count was performed using an automatic ABT Coulter AB Pentra.

$b$ The electrophoretic profile of hemoglobin was confirmed by capillary technique using the SEBIA Minicap Flex Piercing on fresh blood collected on EDTA tube or stored at $2-7^{\circ} \mathrm{C}$ for less than seven days. We have selected the following decision criteria.

c Anemia was defined as hemoglobin $(\mathrm{Hb})<11 \mathrm{~g} / \mathrm{dl}$ and categorized according to the mean corpuscular volume $(\mathrm{MCV})$ : in macrocytic anemia (MCV $>95 \mathrm{fl}$ ), normocytic $(80 \leq \mathrm{MCV} \leq 95 \mathrm{fl})$ and microcytic $(\mathrm{MCV}<$ $80 \mathrm{fl})$. It is considered severe if $\mathrm{Hb}$ was $<7 \mathrm{~g} / \mathrm{dl}$, moderate if $7 \mathrm{~g} / \mathrm{dl} \leq \mathrm{Hb} \leq 9 \mathrm{~g} / \mathrm{dl}$ and light if $9 \mathrm{~g} / \mathrm{dl} \leq$ $\mathrm{Hb} \leq 11 \mathrm{~g} / \mathrm{dl}$. According to the mean hemoglobin content (MCT), ranging from 27 to $31 \mathrm{pg}$, hypochromic anemias $(\mathrm{MCT}<27 \mathrm{pg})$ and normochromic anemias (27 $<\mathrm{MCT}<31 \mathrm{pg}$ ) are distinguished.

$d$ the normal platelet count is between 200000 and $400000 / \mathrm{mm}^{3}$.

e the normal rate of white blood cells between 40000 to $10000 / \mathrm{mm}^{3}$.

\subsection{Molecular Study}

\subsubsection{DNA Extraction by the Qiagen kit (Qiagen, http://www.qiagen.com)}

The use of this kit allowed us to extract the DNA from a

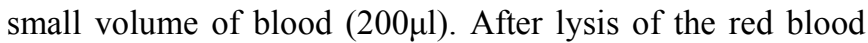
cells, $2 \mathrm{ml}$ of the "FG2" buffer and $20 \mu \mathrm{l}$ of "Qiagen Protease" are added to the white blood cell pellet. The mixture is vortexed 3 to 4 times for 5 seconds and then incubated for $10 \mathrm{~min}$ at $65^{\circ} \mathrm{C}$. Protein digestion gave the mixture a green color. 2 volumes of absolute ethanol are then added to the mixture, which is then centrifuged for 3 minutes at $2000 \mathrm{rpm}$. The precipitated DNA is recovered, washed with $5 \mathrm{ml}$ of $70 \%$ ethanol, dried and finally dissolved in the "FG3" buffer for $1 \mathrm{~h}$ at $65^{\circ} \mathrm{C}$.

\subsubsection{Control of the Purity of the DNA Extracted by Agarose Gel Electrophoresis}

To evaluate the quality of the DNA, we carried out electrophoresis on a $3 \%$ agarose gel in $0.5 \mathrm{x}$ TBE buffer $(4.45 \mathrm{mM}$ 
Tris, 4.45mM Boric acid, 0.1mM EDTA: $\mathrm{pH}=8) .5 \mu \mathrm{l}$ of DNA are added to $1 \mu \mathrm{l}$ of the following blue mixture $(0.25 \%$ of Xylenecyanol, $0.25 \%$ of bromophenol blue and $30 \%$ of glycerol). After migration and visualization under UV, a "smear" shows degraded DNA. On the other hand, a sharp band of high intensity attests to a non-degraded state of the nucleic acid.

\subsubsection{Quantification of DNA by Spectrophotometry}

After DNA extraction, quantification was performed with the Thermo Scientific NanoDrop ${ }^{\text {TM }}$ 330Fluorospectrometer (Wilmington, USA), which automatically measures the nucleic acid concentration.

The maximum absorption of the nucleic acids is $260 \mathrm{~nm}$. Proteins, the main contaminant of nucleic acids, also absorb at $260 \mathrm{~nm}$, but with an absorption maximum of $280 \mathrm{~nm}$ because of the aromatic amino acids. Thus, the ratio $\mathrm{R}=$ A260nm / A280nm makes it possible to assess whether the DNA preparation is contaminated with proteins or ribonucleic acids.

a pure DNA: $1.8<\mathrm{R}<2$

b DNA contaminated with proteins: $\mathrm{R}<1,7$

c DNA contaminated with RNA: $\mathrm{R}>2$

\subsubsection{Determination of Haplotype by Polymerase Chain Reaction-Restriction Fragment Length Polymorphism (PCR-RFLP)}

This research was done using the classical PCR / RFLP method to determine haplotypes related to the $\mathrm{HbS}$ mutation by looking for polymorphisms that create or abolish the restriction site of one of the 5 enzymes used here: XmnI, HindIII, HincII, AvaII and HinfI.

The PCR reaction was performed in a Whatman Biométra thermal cycler.

In our protocol, we used a final volume of $20 \mu$ containing $1 \mu \mathrm{l}$ of genomic DNA $5 \mu \mathrm{l}$ of each of the two primers (supplied by Inqaba Biotech), $10 \mu \mathrm{l}$ on Taq a mixture comprising dNTP, Mgcl2, Taq polymerase (supplied by Inqaba Biotech) and $4 \mu \mathrm{l}$ of bi-distilled water. The reactions are carried out according to a program of 35 cycles. Each cycle comprises 30 seconds of denaturation at $95^{\circ} \mathrm{C}, 20$ seconds of hybridization at $54^{\circ} \mathrm{C}$ and 45 seconds of extension at $72^{\circ} \mathrm{C}$. A last cycle at $72^{\circ} \mathrm{C}$ for 5 min fixes the end of the elongation and thus completes the PCR reaction.

After amplification, the products obtained are digested with the preceding enzymes. The digestion of the amplification product is carried out in a final volume of $20 \mu \mathrm{l}$ comprising: $7 \mu \mathrm{l}$ of amplification product (PCR) $2.5 \mu \mathrm{l}$ of the specific enzyme buffer $0.5 \mu \mathrm{l}$ of enzyme $10 \mu \mathrm{l}$ of water bidistilled. Enzymatic incubation is done at $37^{\circ} \mathrm{C}$ for 16 hours for $\mathrm{XmnI}$ and 3 to $5 \mathrm{~h}$ for the other 4 enzymes. Table 1 shows the sequence of primers and enzymes used in the determination of haplotypes related to the $\beta \mathrm{S}$ mutation.

Table 1. Conditions used when genotyping haplotypes by PCR/RFLP.

\begin{tabular}{|c|c|c|c|c|c|}
\hline Régions & Primers & amplicon size (pb) & Restriction Enzyme & Wild phenotype & Mutation \\
\hline $5^{\prime} \mathrm{G} \gamma$ & $\begin{array}{l}\text { AAC TGT TGC TTT ATA GGA TTT T } \\
\text { AGG AGC TTA TTG ATA ACC TCA GAC }\end{array}$ & 657 & $\mathrm{XmnI}$ & 657 & 455,202 \\
\hline $\mathrm{G} \gamma$ & $\begin{array}{l}\text { TGC TGC TAA TGC TTC ATT ACA A } \\
\text { AAG TGT GGA GTG TGC ACA TGA }\end{array}$ & 782 & Hind III & 782 & 438,344 \\
\hline $\mathrm{A} \gamma$ & $\begin{array}{l}\text { TGC TGC TAA TGC TTC ATT ACA A } \\
\text { TAA ATG AGG AGC ATG CAC ACA C }\end{array}$ & 780 & HindIII & 780 & 436,344 \\
\hline$\Psi \beta$ & $\begin{array}{l}\text { GAA CAG AAG TTG AGA TAG AGA } \\
\text { ACT CAG TGG TCT TGT GGG CT }\end{array}$ & 701 & HincII & 701 & 361,340 \\
\hline $3^{\prime} \psi \beta$ & $\begin{array}{l}\text { TCT GCA TTT GAC TCT GTT AGC } \\
\text { GGA CCC TAA CTG ATA TAA CTA }\end{array}$ & 614 & HincII & 614 & 499,115 \\
\hline $3^{\prime} \delta$ & $\begin{array}{l}\text { TGG ATT CTG CCT AAT AAA A } \\
\text { GGG CCT ATG ACA GGG TAA T }\end{array}$ & 738 & Hinf I & 738 & $\begin{array}{l}341,243,154 / 243 \\
213,154,128\end{array}$ \\
\hline$\beta$ & $\begin{array}{l}\text { GCT GAG GGT TTG AAG TCC AA } \\
\text { CAC TGA TGC AAT CAT TCG TC }\end{array}$ & 803 & AvaII & 803 & $\begin{array}{l}475,328 / 475 \\
214,114\end{array}$ \\
\hline
\end{tabular}

\subsection{Data Collection and Statistical Analysis}

For each patient, the epidemiological, clinical, hematological and molecular data were collected on a survey card which was entered into a computer and analyzed using the CDC (Centre for Disease Control and Prevention) Epi-info 7.0 software, Atlanta, USA. The STUDENT t-test was used for the comparison of the means of the quantitative variables and the chi-2 test for the qualitative variables. The significance threshold for statistical tests was set at $\mathrm{p}<0.05$.

\section{Results}

\subsection{Epidemiological Data}

In total we collected 100 homozygous sickle cell patients during this period. There were 43 boys and 57 girls, a sex ratio of 0.75 . The age of the patients ranged from 15 years to 75 years with an average age of 28 years. The age group most represented was the one whose ages ranged between 15 and 25 years ( 52 cases or $52 \%$ of the population).

\subsection{Clinical Data}

The complications were dominated by vaso-occlusive 
seizures 47 patients (47\%) of the study population of which 38 had two seizures. Table 2 summarizes these complications.

Table 2. Distribution of patients according to observed complications.

\begin{tabular}{lll}
\hline Clinical Complications & $\begin{array}{l}\text { Absolute } \\
\text { Frequency }\end{array}$ & $\begin{array}{l}\text { Relative } \\
\text { Frequency }\end{array}$ \\
\hline Vaso-occlusive attack & 47 & $47 \%$ \\
Anemia & 28 & $28 \%$ \\
Proteinuria & 17 & $17 \%$ \\
Biliary lithiasis & 09 & $09 \%$ \\
Pneumonia & 09 & $09 \%$ \\
Osteonecrosis (hip/shoulder) & 08 & $08 \%$ \\
Priapism & 07 & $07 \%$ \\
Leg ulcer & 07 & $07 \%$ \\
Acute Thoracic Syndrome & 06 & $06 \%$ \\
Stroke & 04 & $04 \%$ \\
Sepsis & 2 & $02 \%$ \\
Ostéomyelitis & 1 & $01 \%$ \\
\hline
\end{tabular}

\subsection{Biological Data}

\subsubsection{Hematological}

The average leukocytosis was of $12345 \pm 6900 / \mathrm{mm}^{3}$ with extremes ranging from 3500 to $49000 / \mathrm{mm}^{3}$. Hyperleukocytosis was observed in $53 \%$ of patients. The average platelet count was $439000 \pm 139330 / \mathrm{mm}^{3}$ with extremes ranging from 180000 to $828000 / \mathrm{mm}^{3} .47 \%$ had thrombocytosis. Mean hemoglobin fractions were $87.78 \%$ for hemoglobin $\mathrm{S} \pm 8.19 \%, 2.72 \pm 1.04 \%$ for hemoglobin $\mathrm{A} 2$ and $9.50 \pm 8.34 \%$ for hemoglobin $\mathrm{F}$, respectively. The degree of anemia was variable, $18 \%$ had severe anemia, $48 \%$ had moderate anemia and $34 \%$ had minor anemia. Table 3 reports the average values of the hematological parameters of the patients.

Table 3. Variations in hematological parameters.

\begin{tabular}{llll}
\hline Hematologic Parameters & Mean \pm standard deviation & Extreme Values \\
\hline Basal Hb $(\mathrm{g} / \mathrm{dl})$ & $8.2 \pm 1.4$ & 05 & -12 \\
$\mathrm{Hb} \mathrm{F}(\mathrm{g} / \mathrm{dl})$ & $9.5 \pm 8.3$ & 00 & -37.5 \\
$\mathrm{Hb} \mathrm{S}(\%)$ & $87.79 \pm 8.2$ & 1 & -98.8 \\
$\mathrm{Hb} \mathrm{A}$ (\%) & $2.7 \pm 1.04$ & 75 & -3 \\
VGM (fl) & $83.2 \pm 3.5$ & 25.9 & -96 \\
CCMH (\%) & $35.28 \pm 3.4$ & 21.5 & -45.5 \\
TCMH (pg) & $31.18 \pm 4.1$ & 3590 & -41.4 \\
White Blood Cells $\left(\mathrm{mm}^{3}\right)$ & $12352 \pm 6.900$ & 128000 \\
Platelets $\left(\mathrm{mm}^{3}\right)$ & $439000 \pm 139000$ & 0.29 \\
CRP $(\mathrm{mg} / \mathrm{l})$ & $12.9 \pm 219$ & -49100 \\
\hline
\end{tabular}

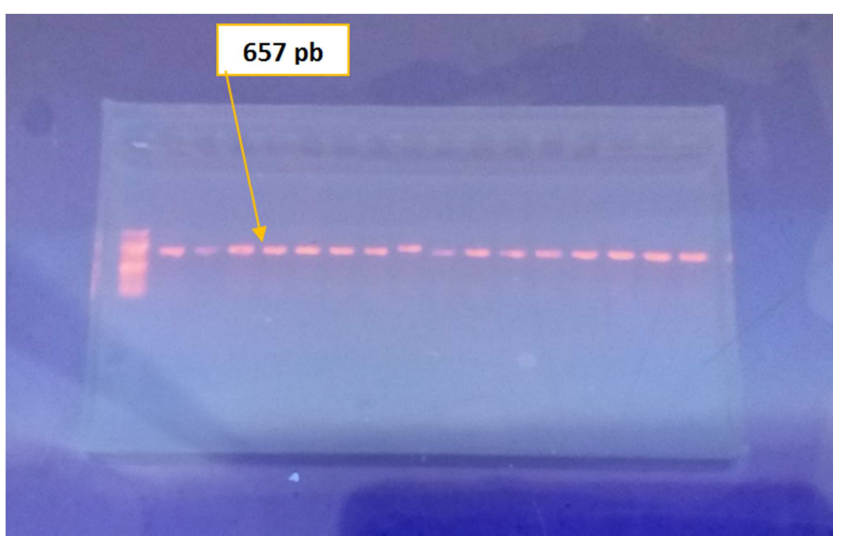

Figure 1. Size of fragments after amplification of region 5 ' $G \gamma$.

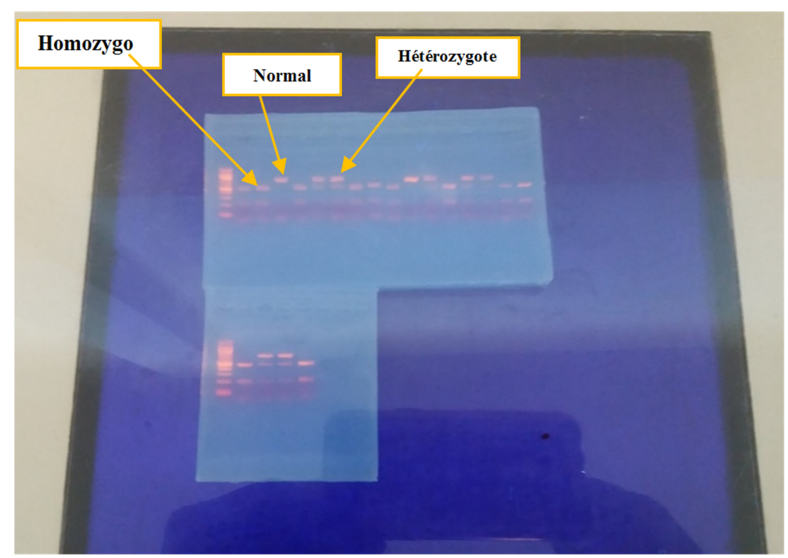

Figure 2. Size of fragments after XmnI digestion.

\subsubsection{Molecular}

The $\mathrm{C} \mathrm{T}$ polymorphism in -158 of $\mathrm{G} \gamma$ which creates a restriction site for XmnI, a characteristic of Senegal haplotypes, was found in $90 \%$ of patients, $58 \%$ of whom were homozygous for this mutation and $32 \%$ heterozygous. The absence of this $\mathrm{C} T$ polymorphism in -158 of $\mathrm{G} \gamma$ and thus the inactivation of the digestion of the PCR product by $\mathrm{XmnI}$ was only found in 8 of the 100 patients participating in the study. The Benin haplotype was found only in one patient. It turned out after verification that this patient was from Benin and whose parents were naturalized Senegalese thereafter. Figures 1 and 2 illustrate the products obtained by PCR of the 5'G $\gamma$ region and after digestion with XmnI.

$$
-a
$$

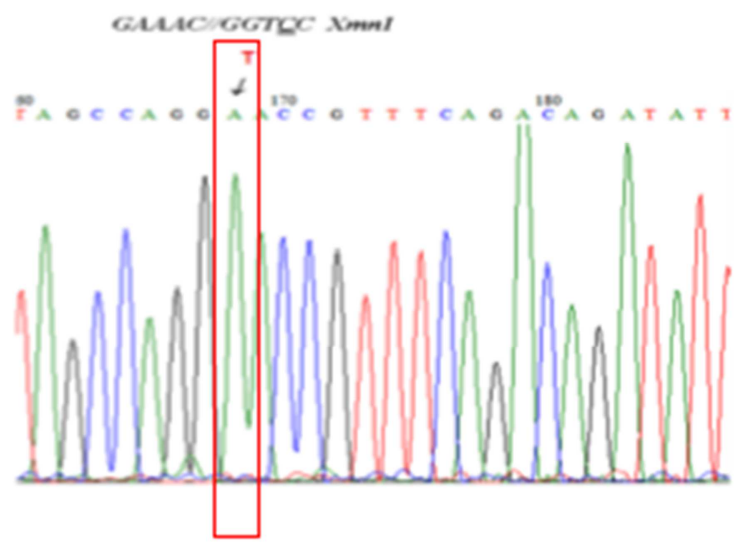

Figure 3. Normal patient without mutation $(-158 T) /(-158 T)$. 
To confirm the above results, the presence or absence of $\mathrm{G} \gamma-158$ polymorphism $\mathrm{C}$ was sought by direct DNA sequencing of 10 different genotype individuals for this polymorphism. The results obtained confirmed the profiles obtained by RFLP (Figures 3, 4, 5).

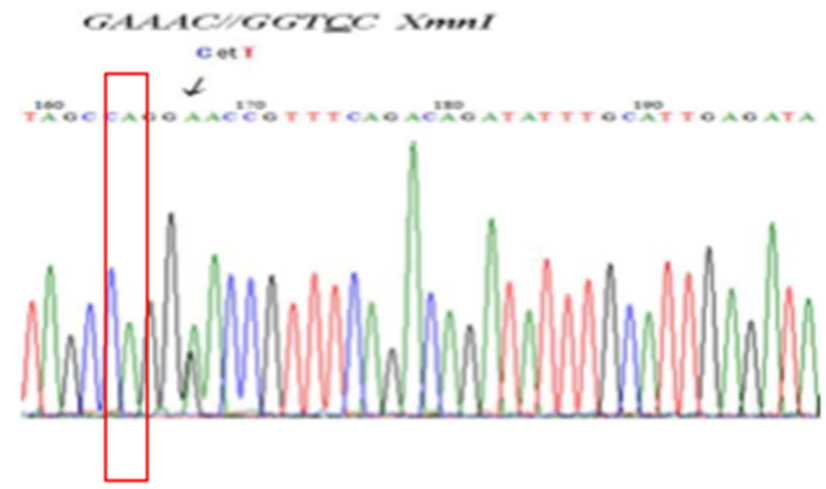

Figure 4. Heterozygous patient for mutation $(-158 C) /(-158 T)$.

$\mathrm{b}$

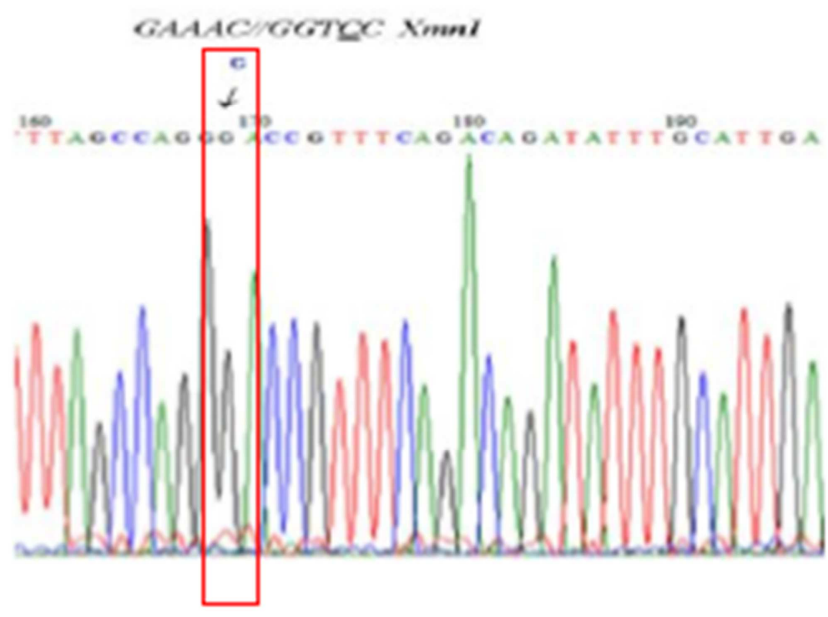

Figure 5. Homozygous patient for mutation $(-158 C) /(-158 C)$.

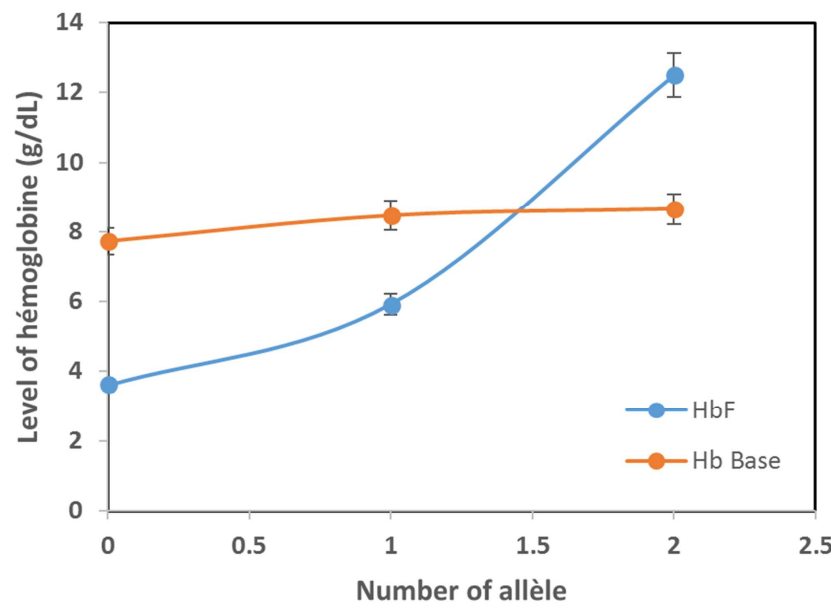

Figure 6. Variation of (HbF, Hb base) according to the allélik frequency.

The bivariate analysis between the presence of this polymorphism and the hemoglobin F level, the basic hemoglobin, shows that these two parameters are correlated statistically significantly with the allelic frequency $(p<0.001)$ (Figure 6).

The comparative analysis between the presence or absence of the polymorphism and the main complications of the disease revealed that the bilary lithiasis correlated with this mutation $\mathrm{p}<0.001$ (Table 4).

Table 4. Influence of Senegal haplotype on the complications of the disease.

\begin{tabular}{llll}
\hline Complications & Normal (\%) & Mutations (\%) & P \\
\hline Vaso-occlusives attacks & $(46.34 \%)$ & $(50.84 \%)$ & 0.747 \\
Infections & $(22.2 \%)$ & $(13.47)$ & 0.321 \\
Acute anemia & $(33.3 \%)$ & $(57.11)$ & 0.846 \\
Bilary lithiasis & $2(22.2 \%)$ & $(8.8 \%)$ & $0.0001 *$ \\
Acute thoracik & $(11.1 \%)$ & $(11.42)$ & 0.07 \\
\hline
\end{tabular}

(*) meaning significant result.

\section{Discussion}

The clinical and biological expression of sickle cell disease varies considerably by geographical region. These differences are largely related to environmental factors (climate, social level, pathologies etc ...) but also to other genetic factors not fully understood. The objectives of this study were to: determine the prevalence of haplotypes linked to the $\beta S$ mutation in Senegalese homozygous sickle cell patients, establish the relationship between these haplotypes and the hemoglobin F level; and finally to study their influence on the main complications of the disease.

Our population consisted of 100 homozygous sickle cell patients; 43 (43\%) male and 57 (57\%) female. Spigorelli et al. [6] in a study on the measurement of pain in adult sickle cell found a female predominance of $59.6 \%$. The median age was 28 years comparable to that found by Ngo Sack et al. [7] who had found an average age of 27 years in his population of 129 sickle cell patients.

Clinically, vaso-occlusive attacks were the most common complication followed by anemia. These results are consistent with those of Diagne et al. [8] where vasoocclusive attacks were the most common clinical manifestation in terms of frequency $(67 \%)$. In addition to their high frequency, vaso-occlusive attacks are the most severe manifestations in adults because they are due to the obstruction of microvessels by stiffened falciform erythrocytes [9]

The hemogram of the sickle cell patients showed a constant anemia $(8.2 \mathrm{~g} / \mathrm{dl})$ during the stationary phases, this is comparable to that observed by Sall-Lopez et al. [10] and confirms the constancy of anemia during homozygous sickle cell disease. This anemia is often normochromic and normocytic with mean levels of MCV and MCT, respectively $83.2 \pm 3.5 \mathrm{fl}$ and $31 \pm 4.1 \mathrm{pg}$ as other authors have described $[11,12]$. There is also leukocytosis and a tendency of thrombocytosis. Leukocytosis is consistently observed in homozygous sickle cell patients in the absence of any bacterial infection [13]. The mechanism underlying this increase of leucocytes is little known. It seems that this is 
related to the chronic inflammation that characterizes sickle cell disease, inflammation fostered by adhesive interactions between different cells and pro-inflammatory cytokines. Among the factors that stimulate leukocyte production, a good correlation has been observed between the plasma level of GMCSF (Granulocyte Monocyte Colony Stimulating Factor) and the total number of leucocytes [14]. In this study, the elevation of CRP favors inflammation since it correlates statistically significantly with leukocytosis $(\mathrm{r}=0.72, \mathrm{p}<$ $0.01)$.

The hemoglobin F observed in our series of homozygous sickle cell patients corresponds to the values described in sickle cell populations carrying the Senegal haplotype [15, 16]. Hemoglobin $F$ has the property of inhibiting the polymerization of hemoglobin $\mathrm{S}$ by interposing itself in the deoxyhemoglobin $S$ polymer, thereby inhibiting the progression of the formation of hemoglobin $\mathrm{S}$ fibers and thereby decreasing cell stiffness [7]. A recent study has shown that an increase in hemoglobin F in SS patients with sickle cell disease was associated with a decrease in inflammation and lipid peroxidation, demonstrating the beneficial and protective role of fetal hemoglobin [17].

The molecular study made it possible to determine the nature and the frequency of haplotypes related to the mutation of hemoglobin $\mathrm{S}$ in the Senegalese population. This study, carried out by PCR / RFLP, showed that the Senegal haplotype was homogeneous in the Senegalese sickle cell population. These results confirm those of a previous study carried out on the Senegalese population [15]. In this study we noted a difference in allelic frequency and correlation with hemoglobin F. Thus, in patients homozygous for this mutation, the rate was relatively higher than that of heterozygous patients and those without the mutation. This difference being statistically significant ( $p<0.001)$. Similar results have been found in several African studies [16, 17]. The baseline hemoglobin level was also correlated with the allele frequency difference ( $p$ $<0.001)$. In patients homozygous for the mutation, the baseline hemoglobin level was higher than the heterozygous and non-mutation patients. These results confirm the beneficial role of hemoglobin $\mathrm{F}$ in decreasing sickling and overall hemolysis. Many studies suggest that the haplotype may be a factor in the phenotypic heterogeneity of sickle cell patients [18, 19]. Indeed, some haplotypes are associated with more severe forms, this is the case of the Bantu haplotype. The most moderate form is associated with the Senegal and Arab-Indian haplotype [19]. In this study, only bilary lithiasis was statistically significantly correlated with the Senegal haplotype $(p<0.001)$ suggesting the role of the haplotype in reducing overall hemolysis and sickling. This result is important because of the frequent association between homozygous sickle cell disease and bilary lithiasis. According to several authors, the prevalence of gallstones among homozygotes varies from one country to another, 34 to $70 \%$ in the United States, $29 \%$ in Jamaica, 4 to $25 \%$ in Africa and $8 \%$ in Saudi Arabia [20, 21]. However, due to our low sample size, a longitudinal study with a larger sample size is necessary to better appreciate the influence of this haplotype on the main complications overall and particularly on the bilary lithiasis.

\section{Conclusion}

This study confirms the homogeneity of the Senegal haplotype in the Senegalese sickle cell population and its influence on the synthesis of hemoglobin F. The haplotypes of beta globin associated with the hemoglobin F level lead to a hemolytic or vaso-occlusive profile. Their influence in a given population depends on their frequency and the rate of correlation with hemoglobin F. These genetic factors can make it possible to predict early the type of expression of sickle cell disease and to adapt the follow-up and the treatment.

\section{Acknowledgements}

We thank the entire cohort of patients at the National Blood Transfusion Center for their commitment to participate in our study. Thanks also go to the various services that helped us in the study of our patients.

\section{Conflict of Interest}

The authors declare that they have no conflict of interest

\section{Authors Contribution}

All authors contributed to conception and design, manuscript preparation, read and approved the final manuscript.

\section{References}

[1] Pagnier J, Mears JG, Dunda-Belkhodja O, Schaefer-Rego KE, Beldjord C, Nagel RL et al. (1984) Evidence for the multicentric origin of the sickle cell hemoglobin gene in Africa. Proc Natl Acad Sci USA; 81: 1771-3.

[2] Lai Y, Chen Y, Chen B, Zheng H, Yi S, Li G, et al. (2016) Genetic Variants at BCL11A and HBS1L-MYB loci Influence $\mathrm{Hb} F$ Levels in Chinese Zhuang $\beta$-Thalassemia Intermedia Patients. Hemoglobin; 40(6): 405-10.

[3] Neonato, M. G., M. Guilloud-Bataille, P. Beauvais, P. Begue, M. Belloy, M. Benkerrou, R. Ducrocq, M. MaierRedelsperger, M. de Montalembert, B. Quinet, J. Elion, J. Feingold and R. Girot (2012) . "Acute clinical events in 299 homozygous sickle cell patients living in France. French Study Group on Sickle Cell Disease." Eur J Haematol; 65(3): 155-164.

[4] Labie D, Elion J. (2003) Génétique et physiopathologie de la drépanocytose. In «La Drépanocytose». Girot R, Begué P, Galacteros F. John Libbey Eurotext ed, Paris, 1-11.

[5] Figueiredo MS, Kerbauy J, Gonçalves MS, Arruda VR, Saad ST, Sonati MF et al. (1996) Effect of alpha-thalassemia and beta-globin gene cluster haplotypes on the hematological and clinical features of sickle cell anemia in Brazil. Am J Hematol; 53: $62-72$. 
[6] Signorelli AA, Ribeiro SB, Moraes-Souza H, et al. (2013) Pain measurement as part of primary healthcare of adult patients with sickle cell disease. Rev Bras Hematol Hemoter.; 35(4): 272-7.

[7] Ngo Sack F, Seck M, Faye B, Diop S. (2016) Morbidité et Aspects Evolutifs de la Drépanocytose SC: Une Étude de 129 Patients au Service d'Hématologie Clinique de Dakar. Health Sci. Dis; 17 (4): 58-62.

[8] Diagne I, Ndiaye O, Moreira C, Signate -Sy H, Camara B. (2000) Les syndromes drépanocytaires majeurs à Dakar (Sénégal) Arch Pédiatr. 7(1): 16-24.

[9] Habibi, A., Bachir, D., Godeau, B. (2004) "Complication aiguës de la drépanocytose." La Revue du Practicien (54): 1548-1556.

[10] Sall L, Diop A, Diagne I, Cissé A, Niang MS, Gueye PM, Diarra M. (2004) Apport des récepteurs solubles de la transferrine dans l'évaluation du statut en fer au cours de la drépanocytose homozygote. Ann. Biol. Clin; 62(4): 415-421.

[11] Girot R. (1997) Drépanocytose chez l'enfant. Encycl Med Chir Pédiatrie 4-080-A-20. Paris: Elsevier.

[12] Lefevre F. (1999) Hématologie et transfusion. $3^{\text {ème }}$ Edition. Paris: Estem et Med-line.

[13] Maier-Redelsperger M, Bardakdjian-Michau J, Neonato MG, Girot R Diagnostic biologique des syndromes drépanocytaires In Girot R, Begué P, Galacteros F. (2003) La Drépanocytose. John Libbey Eurotext Ed, Paris, 3-29.

[14] Conran N, Saad ST, Costa FF, Ikuta T (2007) Leucocyte numbers correlate with plasma levels of granulocytemacrophage colony-stimulating factor in sickle cell disease. Ann Hematol; 86: 255-61.

[15] Nagel RL, Fabry ME, Pagnier I, Zohoun I, Waciman H et al. (1993) Haematologically and genetical distinct forms of sickle cell anemia in Africa. The Senegal type and Benin type. N Engl J Med; 312: 880-884.

[16] Veten MF, Isselmou O. Abdelhamid, Meiloud GM, Sidi M,Ghaber, Salem M, ,Abbes S,.Houmeida AO.( 2012) Hb S

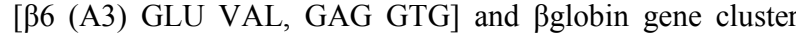
haplotype distribution in Mauritania Hemoglobin, ISSN: 0363-0269 DOI: 10.3109/03630269.2012.688782.

[17] Bhagat S, Patra PK, Thakur AS. (2012 ) Association between XmnI Polymorphism and HbF Level in Sickle Cell Disease Patients from Chhattisgarh Int J Biomed Sci. 8(1):36-9.

[18] Wonkam A, Ngo Bitoungui VJ, Vorster AA, Ramesar R, Cooper RS, Tayo B, et al. (2014) Association of variants at BCL11A and HBS1L-MYB with hemoglobin $F$ and hospitalization rates among sickle cell patients in Cameroon. PloS One.; 9(3):e92506.

[19] Steinberg MH, Sebastiani P. (2012) Genetic modifiers of sickle cell disease. Am J Hematol.; 87(8):795-803.

[20] Seguier LP, Lagausie P, Benchekroum M, Di Napolis AY. (2001) Elective laparoscopic cholecystectomy. Treatment of choice for lithiasis in children with sickle cell disease. Surg Endosc; 15: 301-4.

[21] Metaxa A, Isatra I, Koussi A. (2002) Lithiase biliaire chez les patients drépanocytaires. Arch pediatr; 8: 878. 